\title{
ANALISIS SIMPAN PINJAM PEREMPUAN PROGRAM NASIONAL \\ PEMBERDAYAAN MASYARAKAT MANDIRI PEDESAAN (SPP-PNPM-MP) \\ TERHADAP PENINGKATAN PENDAPATAN MASYARAKAT \\ KECAMATAN PEMAYUNG KABUPATEN BATANG HARI \\ (STUDI KASUS DESA OLAK RAMBAHAN DAN DESA SELAT)

\author{
oleh: \\ *) Agus Santoso \\ *) Dosen Tetap Stie Muhammadiyah Jambi
}

\begin{abstract}
Ringkasan
Penelitian ini bertujuan untuk mengetahui dan menganalisis perbedaan pendapatan masyarakat penerima Simpan Pinjam Perempuan Program Nasional Pemberdayaan Masyarakat Mandiri Perdesaan (SPP-PNPM-MP) sebelum dan sesudah adanya PNPM-MP di Desa Olak Rambahan dan Desa Selat Kecamatan Pemayung Kabupaten Batanghari, serta untuk mengetahui permasalahan dan faktor-faktor yang menyebabkan keberhasilan pengembalian pinjaman pada Program SPP- PNPM -MP.

Data yang digunakan dalam penelitian ini adalah data hasil survey dengan menggunakan metode analisis kuantitatif deskriptif dengan menggunakan uji beda 2 rata-rata untuk mengukur perbedaan tingkat pendapatan masyarakat sebelum dan sesudah penerima SPP-PNPM-MP.

Hasil penelitian menunjukan bahwa pendapatan masyarakat berdasarkan sebelum mendapatkan program SPP-PNPM-MP adalah sebesar 1,94636, sedangkan tingkat pendapatan masyarakat sesudah SPP-PNPM-MP adalah sebesar 3,37006, kemudian desa Selat sebelum mendapatkan program SPP-PNPM-MP adalah sebesar 1,04346, sedangkan tingkat pendapatan masyarakat sesudah SPP-PNPM-MP adalah sebesar 1,70016 Selanjutnya penyebab SPPPN PMMP yang bermasalah disebabkan kurangnya koordinasi antar kelompok serta kurangnya transparansi, kemudian kurangnya itikad untuk membayar bagi anggota kelompok.
\end{abstract}

Kata kunci: Simpan Pinjam Perempuan Program Nasional Pemberdayaan Masyarakat Mandiri Perdesaan, pendapatan

\section{Pendahuluan}

Penelitian ini bertujuan untuk mengetahui dan menganalisis perbedaan pendapatan masyarakat penerima Simpan Pinjam Perempuan Program Nasional Pemberdayaan Masyarakat Mandiri Perdesaan (SPP-PNPM-MP) sebelum dan sesudah adanya PNPM-MP di Desa Olak Rambahan dan Desa Selat Kecamatan Pemayung Kabupaten Batanghari, serta untuk mengetahui permasalahan dan faktor-faktor yang menyebabkan keberhasilan pengembalian pinjaman pada Program SPP- PNPM -MP.

Data yang digunakan dalam penelitian ini adalah data hasil survey dengan menggunakan metode analisis kuantitatif deskriptif dengan menggunakan uji beda 2 rata-rata untuk mengukur perbedaan tingkat pendapatan masyarakat sebelum dan sesudah penerima SPP-PNPM-MP. 
Hasil penelitian menunjukan bahwa pendapatan masyarakat berdasarkan perhitungan SPPS 17.0 sebelum mendapatkan program SPP-PNPM-MP adalah sebesar 1,94636, sedangkan tingkat pendapatan masyarakat sesudah SPP- PNPM-MP adalah sebesar 3,37006, kemudian desa Selat sebelum mendapatkan program SPP-PNPM-MP adalah sebesar 1,04346, sedangkan tingkat pendapatan masyarakat sesudah SPP-PNPM-MP adalah sebesar 1,70016

Selanjutnya penyebab SPPPNPMMP yang bermasalah disebabkan kurangnya koordinasi antar kelompok serta kurangnya transparansi, kemudian kurangnya itikad untuk membayar bagi anggota kelompok. Sementara itu untuk meberikan solusi dari permasalahan tersebut harus memiliki langkah-langkah yang tepat seperti koordinasi dan tanggungjawab antar kelompok.

Rekomendasi Diaharapkan tingkat pendapatan masyarakat penerima SPP Mandiri Pedesaan sebelum dan sesudah adanya SPP-PNPM Mandiri Pedesaan dapat memberikan memotivasi untuk berpatisipasi dalam setiap tahapan SPP- PNPM Mandiri Pedesaan sehingga makin berkembang, serta dalam proses seleksi terhadap penerima SPP harus di tingkatkan lagi, serta progran SPP- PNPM Mandiri pendesaan ini dapat dilanjutkan oleh pemerintah daerah kabupaten secara berkesinambungan sehingga, akan meningkatkan pendapatan dan kesejahteraan mayarakat Olak Rambahan dan masyarakat Selat maupun masyarakat Batanghari secara umum dalam berbagai bidang usaha, selanjutnya diharapkan koordinasi antar kelompok terus terjaga sehingga komunikasi antar kelompok terjalin dengan baik, selanjutnya adanya transparansi dan tanggungjawab antar anggota.

PNPM-MP sesungguhnya merupakan upaya untuk mengurangi akar kemiskinan di pedesaan. Berdasarkan beberapa studi, kemiskinan terjadi karena minimnya pendapatan didalam keluarga. Pendapatan keluarga yang minim terjadi karena ketiadaannya kegiatan ekonomi produktif, Penciptaan dan pengembangan ekonomi produktif didalam keluarga memiliki peran yang strategis, terutama kegiatan ekonomi produktif yang berkelanjutan dan stabil. Tetapi yang menjadi tantangan didalam penciptaan dan pengembangan ekonomi produktif adalah adanya keterbatasan sumber daya khususnya permodalan. Jikapun ada kegiatan ekonomi produktif belumlah bersifat memberdayakan ekonomi keluarga.

Adanya keterbatasan permodalan didalam penciptaan dan pengembangan ekonomi produktif telah direspon oleh PNPM MP melalui program SPP yaitu simpan pinjam perempuan. SPP ini khusus ditujukan untuk perempuan untuk mengakomodir usulan dan menjadi katalisator peningkatan perekomian rumah tangga miskin dimana kaum perempuan terutama kaum ibu menjadi motor penggeraknya. 
Adapun lingkup kegiatan PNPM Mandiri pedesaan pada prinsipnya merupakan peningkatan kesejahteraan dan kesempatan kerja masyarakat miskin pedesaan secara mandiri melalui peningkatan partisipasi masyarakat terutama masyarakat miskin, kelompokm perempuan, dan kelompok komoditas yang terpinggirkan. Meningkatnya kapasitas kelembagaan Pemerintah dan Masyarakat, meningkatnya modal sosial masyarakat serta inovasi dan pemanfaatan Teknologi Tepat Guna. Oleh karena itu dalam pelaksanaannya PNPM Mandiri Pedesaan di bagi menjadi 2 (dua) kegiatan antara lain:

1. Kegiatan Simpan Pinjam Perempuan (SPP) sebesar $25 \%$.

2. Kegiatan yang bersifat Open Menu sebesar $75 \%$.

Secara umum kegiatan Simpan Pinjam Perempuan ini bertujuan untuk mengembangkan potensi kegiatan simpan Pinjam Perempuan yang berada di Pedesaan, kemudahan akses pendanaan usaha skala mikro, pemenuhan kebutuhan pendanaan sosial dasar, dan memperkuat kelembagaan kegiatan kaum perempuan serta mendorong pengurangan rumah tangga miskin dan penciptaan lapangan kerja.

Sedangkan kegiatan yang bersifat open menu adalah bahwa masyarakat dapat mengusulkan apa saja, sepanjang yang tidak kegiatan yang dilarang (negative list). Semua aspirasi masyarakat yang ditampung atau dihimpun melalui musyawarah desa agar tidak menyimpang dengan tujuan bidang prasarana dan sarana PNPM Mandiri Pedesaan, yang betulbetul yang sangat dibutuhkan oleh masyarakat, sehingga dapat mendukung peningkatn ekonomi, derajat kesehatan, pendidikan dan peningkatan kapasitas masyarakat, serta dapat memperhitungkan aspek berkelanjutan (bermanfaat, berkualitas, dapat di pergunakan untuk kebutuhan kebutuhan masyarakat.

Dengan demikian dalam memberikan wewenang secara proporsional kepada masyarakat dalam membangun diri dan lingkungannnya, sehingga akan dapat tercipta kegiatan pembangunan partisipatif yang lebih aspiratif terhadap kebutuhan masyarakat. Pemerintah pusat menciptakan program pemberdayaan masyarakat yaitu PNPM Mandiri Pedesaan dengan salah satu kegiatan yang berbeda pada program pemerintah sebelumnya, yaitu Simpan Pinjam Perempuan.

\section{Tinjauan Pustaka}

Dalam kehidupan sehari hari-hari di tengah-tengah masyarakat pendapatan yang nantinya akan melambangkan kekayaan dan status sosial tetap di jadikan tolok ukur keberhasilan atau kesuksesan seseorang karenanya pendapatan sebagaimana dikemukakan 
Soekirno (1980) merupakan sasaran akhir atau tujuan utama yang hendak di capai oleh setiap orang.

Mubyarto (1989) mengemukakan bahwa pendapatan adalah seluruh penerimaan baik berupa uang atau barang dari hasil usaha atau produksi. Sementara pendapatan rumah tangga dapat diartikan sebagai jumlah keseluruhan dari pendapatan formal, informal dan sub-sub sistim. Pendapatan formal adalah penghasilan yang di peroleh melalui pekerjaan pokok, sedangkan pendapatan informal di peroleh melalui pekerjaan di luar pekerjaan pokok dan pendapatan sub sistem adalah penghasilan yang di peroleh dari faktor produksi yang di nilai dengan uang.

Badan Pusat Statistik (BPS) mendefenisikan pendapatan rumah tangga atau balas jasa faktor-faktor produksi. Ada keterkaitan yang erat antara pendapatan, faktor-faktor produksi dan tingkat kesejahteraan suatu rumah tangga. (Partadireja, 1985) mendefenisikan pendapatan adalah "hasil berupa uang atau hasil materil lainnya yang di capai dari pada penggunaan kekayaan atau jasa-jasa manusia bebas" mengenai pendapatan yang dimaksud disini adalah pendapatan masing-masing rumah tangga yang diterima rata-rata setiap bulannya. Pendapatan tersebut baik berupa uang atau barang, disamping itu perhitungan pendapatan di dapatkan secara langsung dengan memperhitungkan gaji pokok di tambah dengan harga pergantian natura, biaya transport, serta tunjangan atau gaji pokok dalam hubungan dengan jumlah anggota keluarga dan masa kerja.

Pengertian pendapatan rumah tangga diatas mempunyai arti bahwa pendapatan terdiri dari pendapatan dalam bentuk uang dan barang yang memiliki nilai yang sama dengan uang. Namun demikian dalam konteks usaha penerima Simpan pinjama perempuan (SPP) PNPMMandiri Pedesaan penerimaan dapat berupa hasil usaha yang dijalankan dan dalam bentuk uang apabila telah dijual. Menurut Hermanto (1996) penerimaan usaha adalah penerimaan dari semua sumber yang dilakukan penerima SPP yang meliputi: 1. Jumlah penambahan inventaris. 2. Nilai penjualan hasil. 3. Harga pembelian dikurangi penyusutan.

Berdasarkan konsep diatas usaha menambah faktor produksi dapat di kategorikan sebagai pendapatan penerima simpan pinjam perempuan. Namun pada pokoknya yang mempengaruhi pendapatan dari usaha adalah nilai penjualan hasil usaha. Hal ini sejalan dengan pendapatan Wisnuaji (1995) pendapatan usaha penerima SPP adalah selisih antar penerimaan dan semua biaya.

\section{Kemiskinan}


Kemiskinan merupakan salah satu masalah klasik yang selalu dihadapi oleh manusia, meskipun seringkali kehadirannya tidak disadari sebagai suatu masalah yang nyata dalam kehidupan sehari-hari. Bagi manusia yang tergolong miskin merasakan dan menjalani sendiri belum tentu baru sadar akan kemiskinan yang di alaminya. Kesadaran itu baru muncul pada saat membandingkan kehidupannya dengan kehidupan orang lain, yang mempunyai tingkat kehidupan sosial dan ekonomi tergolong lebih tinggi.

Menurut ADB (2008) Kemiskinan terkait dengan ketidak mampuan dan tidak adanya kesempatan bagi rakyat miskin untuk mengakses, ikut serta dan mengambil manfaat dari proses-proses ekonomi, sosial dan politik bangsa serta masyarakatnya. Kemiskinan memiliki arti yang lebih luas dari sekedar perbedaan tingkat pendapatan atau konsumsi antar individu berdasarkan standar kesejahteraan terukur seperti asupan kalori minimum atau garis kemiskinan yang sudah ditentukan sebelumnya. Kemiskinan juga terkait dengan ketidakmampuan mencapai faktor-faktor di luar pendapatan (non-income factors) seperti akses ke layanan publik dan infrastruktur dasar (kesehatan, pendidikan, sanitasi dan air bersih). Terakhir, kemiskinan harus dilihat dari perspektif apakah dan bagaimana rakyat miskin dapat, atau diizinkan, turut serta dalam proses penyusunan dan pengambilan keputusan tentang rencana dan anggaran pembangunan komunitasnya serta dalam pelaksanaan program-program yang berpihak pada rakyat miskin.

\section{Ciri-Ciri Kemiskinan}

Kemiskinan di Indonesia identik dengan pedesan, dalam arti bahwa masyarakat yang tergolong miskin lebih banyak berada di daerah pedesaan. Kegiatan secara umum dengan, dimana rata-rata kegiatan penduduk dengan mata pencaharian sebagai petani.

Salim (1980) menyampaikan empat ciri-ciri penduduk yang berada di bawah garis kemiskinan, yaitu: 1. Rendahnya tingkat pendidikan karena waktunya tersita untuk mencari nafkah dan memperoleh penghasilan; 2. Sebagian besar masyarakat miskin tinggal didaerah pedesaan semenjak kecil/ rendah; 3. Masyarakat miskin pada umumnya tidak mempunyai faktor produksi seperti tanah, modal ataupun keterampilan; 4. Kemungkinan untuk memperoleh asset produksi dengan kekuatan sendiri sangat sulit.

\section{Faktor-Faktor Penentu Kemiskinan.}

Sejalan dengan definisi kemiskinan yang berbasis pada hak-hak dasar, permasalahan kemiskinan perlu dilihat dari pendapat atau persepsi yang dikemukakan oleh masyarakat miskin itu sendiri dan diperkuat dengan data statistik. Permasalahan 
kemiskinan akan dilihat dari aspek pemenuhan hak dasar, beban kependudukan, serta ketidakadilan dan ketidaksetaraan gender.

\section{Terbatasnya Kesempatan Kerja dan Berusaha}

Masyarakat miskin umumnya menghadapi permasalahan terbatasnya kesempatan kerja dan berusaha, terbatasnya peluang mengembangkan usaha, lemahnya perlindungan terhadap aset usaha, dan perbedaan upah serta lemahnya perlindungan kerja terutama bagi pekerja anak dan pekerja perempuan seperti buruh migran perempuan dan pembantu rumah tangga. Keterbatasan modal, kurangnya keterampilan, dan pengetahuan, menyebabkan masyarakat miskin hanya memiliki sedikit pilihan pekerjaan yang layak dan peluang yang sempit untuk mengembangkan usaha. Terbatasnya lapangan pekerjaan yang tersedia saat ini seringkali menyebabkan mereka terpaksa melakukan pekerjaan yang beresiko tinggi dengan imbalan yang kurang memadai dan tidak ada kepastian akan keberlanjutannya.

Kesulitan ekonomi yang dihadapi keluarga miskin seringkali memaksa anak dan perempuan untuk bekerja. Pekerja perempuan, khususnya buruh migran perempuan dan pembantu rumahtangga dan pekerja anak menghadapi resiko sangat tinggi untuk dieksplotasi secara berlebihan, serta tidak menerima gaji atau digaji sangat murah, dan bahkan seringkali diperlakukan secara tidak manusiawi. Oleh karena itu, pekerja perempuan dan anak memerlukan perlindungan kerja yang lebih dan khusus, karena lebih rentan untuk mengalami pelanggaran hak dan eksploitasi secara berlebihan.

\section{Konsep Pemberdayaan Masyarakat.}

Istilah Pemberdayaan pertama kali digunakan oleh aktivis Gerakan Black Panther dalam mobilisasi politik di USA pada 1960-an. Konsep ini dorman selama decade 1970-an. Pada pertengahan decade 1980-an, Gerakan Kaum Wanita mempopulerkan kembali konsep pemberdayaan kini konsep " Pemberdayaan " telah masuk keberbagai disiplin ilmu, baik pada tataran teori maupun prektek. Bahkan, istilah " telah menjadi suatu kata plastis, yang digunakan dalam berbagai kontek, sehingga mengaburkan makna yang sebenarnya (Aithai Vathsala, 2005:2).

Pemberdayaan atau dalam bahasa Inggris disebut Empowerment merupakan suatu konsep yang lahir sebagai bagian dari perkembangan alam pemikiran masyarakat di Eropa maupun Asia, yang mengakui pentingnya unsur rumah tangga sebagai objek yang perlu ditumbuh- kembangkan kegiatan 
perekonomiannya. (Pranarka dan Moeljarto, 1996) Sedangkan menurut Taylor 1994 dalam Prijono (1996) pemberdayaan perempuan (women empowerment is a process center on unstanding women"s subordination and in creating the condition under which disadvantages people to meet their dailly needs and actively participate in the development of structure that realize social, political and economic rights.) yaitu bahwa pemberdayaan perempuan merupakan proses penting dalam memahami kedudukan wanita, dan penciptaan kondisi dengan segala kelemahannya untuk memenuhi kebutuhan hidup sehari-harinya, dan berpartisipasi aktif dalam pembangunan yang berkaitan dengan hak pembangunan sosial, politik dan ekonomi.

\section{Tujuan dan sasaran Pemberdayaan Masyarakat}

Pemberdayaan merupaka upaya peningkatan harkat lapisan masyarakat dan pribadi manusia. Upaya ini meliputi pertama mendorong memotivasi, meningkatkan kesadaran akan potensinya dan menciptakan iklim/suasana untuk berkembang. Kedua memperkuat daya, potensi yang dimiliki dengan langkah-langkah positif memperkembangkannya. Ketiga penyediaan berbagai masukan dan pembukaan akses ke peluang-peluang. Upaya pokok yang dilakukan adalah peningkatan taraf pendidikan, derajat kesehatan, akses kepada modal, teknologi tepat guna, informasi, lapangan kerja dan pasar dengan fasilitas- fasilitasnya.

Adapun tujuan pemberdayaan masyarakat pada dasarnya sebagai berikut:

1. Membantu pengembangan manusia yang otentik dan integral dari masyarakat lemah, rentan, miskin, marginal dan kaum kecil seperti petani kecil, buruh tani, masyarakat miskin perkotaan, masyarakat adat terbelakang, kaum muda pencari kerja, kaum cacat dan kelompok wanita yang didiskriminil/ di kesampingkan.

2. Memberdayakan kelompok-kelompok masyarakat tersebut secara sosio ekonomis sehingga dapat mememenuhi kebutuhan dasar hidup, namun sanggup berperan serta dalam pengembangan masyarakat.

Sasaran-sasaran program pemberdayaan masyarakat dalam mencapai kemandirian sebagai berikut:

1. Terbukanya kesadaran dan tumbuhnya keterlibatan masyarakat akar rumput dalam mengorganisir diri untuk kemajuan dan kemandirian bersama.

2. Diperbaikinya kondisi sekitar kehidupan kaum perempuan, rentan, lemah, tak berdaya, miskin dengan kegiatan-kegiatan peningkatan pemahaman, peningkatan pendapatan dan usaha-usaha kecil di berbagai bidang ekonomi kea rah swadaya. 
3. Ditingkatkan kemampuan dan kinerja kelompok-kelompok swadaya dalam keterampilan teknis dan manajemen untuk perbaikan produktifitas dan pendapatan mereka.

\section{Ruang lingkup Pemberdayaan Masyarakat.}

Pemberdayaan harus dilakukan secara terus menerus, komprehensif dan simultan, sampai ambang batas tercapainya keseimbangan yang dinamis antara yang di perintah dan di perintah. Menurut Ndraha (2000:80) di perlukan berbagai Program Pemberdayaan sebagai berikut:

1. Pemberdayaan Politik; bertujuan meningkatkan bargaining position yang di perintah terhadap perintah, di perintah mendapatkan apa yang merupakan haknya dalam bentuk barang, jasa, layanan dan kepedulian tanpa merugikan orang lain.

2. Pemberdayaan Sosial Budaya; bertujuan meningkatkan kemampuan sumber daya manusia (human right), penggunaaan (human utilization) dan perlakuan seadil adilnya terhadap manusia.

3. Pemberdayaan ekonomi; sebagai upaya untuk meningkatkan kemampuan yang diperintah sebagai konsumen untuk berfungsi sebagai penanggung dampak negatif pertumbuhan, pembayar resiko salah urus, pemikul beban pembangunan, kambing hitam kegagalan program dan penderita kerusakan lingkungan.

4. Pemberdayaan lingkungan; sebagai program perawatan dan pelestarian lingkungan supaya antara yang di perintah dan lingkungannya terhadap hubungan saling menguntungkan.

\section{Pendekatan Dalam Pemberdayaan Masyarakat}

Menurut Kartasasmita (2003) Strategi pembangunan yang bertumpu pada pemihakan dan pemberdayaan dipahami sebagai suatu proses transformasi dalam hubungan sosial, ekonomi, budaya dan politik masyarakat. Perubahan struktural yang diharapkan adalah proses yang berlangsung secara alamiah, yaitu yang menghasilkan harus menikmati. Begitu pula sebaliknya yang menikmati haruslah yang menghasilkan. Teori- teori ekonomi makro, yang umumnya bersandar pada peran pasar dalam alokasi sumber daya, serta dengan beranggapan bahwa kebijaksanaan ekonomi makro yang tepat akan menguntungkan semua lapisan masyarakat, dalam kenyataannya tidak dapat menghasilkan jawaban yang memuaskan bagi masalah kesenjangan. Kekuatan sosial yang tidak berimbang, menyebabkan kegagalan pasar untuk mewujudkan harapan itu. Oleh karena itu, diperlukan intervensi yang tepat, agar kebijaksanaan pada tingkat makro mendukung upaya mengatasi kesenjangan yang 
harus dilakukan dengan kegiatan yang bersifat mikro dan langsung ditujukan pada lapisan masyarakat terbawah.

Pemberdayaan masyarakat dapat dipandang sebagai jembatan bagi konsepkonsep pembangunan makro dan mikro. Dalam kerangka pemikiran itu berbagai input seperti dana, prasarana dan sarana yang dialokasikan kepada masyarakat melalui berbagai program pembangunan harus ditempatkan sebagai rangsangan untuk memacu percepatan kegiatan sosial ekonomi masyarakat. Proses ini diarahkan untuk meningkatkan kapasitas masyarakat (capacity building) melalui pemupukan modal yang bersumber dari surplus yang dihasilkan dan pada gilirannya dapat menciptakan pendapatan yang dinikmati oleh rakyat. Proses transformasi itu harus digerakkan oleh masyarakat sendiri.

\section{Latar Belakang PNPM MP}

Mulai tahun 2007 Pemerintah Indonesia mencanangkan Program Nasional Pemberdayaan Masyarakat (PNPM) Mandiri yang terdiri dari PNPM Mandiri Perdesaan, PNPM Mandiri Perkotaan, serta PNPM Mandiri wilayah khusus dan desa tertinggal. PNPM Mandiri Perdesaan adalah program untuk mempercepat penanggulangan kemiskinan secara terpadu dan berkelanjutan. Pendekatan PNPM Mandiri Perdesaan merupakan pengembangan dari Program Pengembangan Kecamatan (PPK), yang selama ini dinilai berhasil. Beberapa keberhasilan PPK adalah berupa penyediaan lapangan kerja dan pendapatan bagi kelompok rakyat miskin, efisiensi dan efektivitas kegiatan, serta berhasil menumbuhkan kebersamaan dan partisipasi masyarakat.

Visi PNPM Mandiri Perdesaan adalah tercapainya kesejahteraan dan kemandirian masyarakat miskin perdesaan. Kesejahteraan berarti terpenuhinya kebutuhan dasar masyarakat. Kemandirian berarti mampu mengorganisir diri untuk memobilisasi sumber daya yang ada di lingkungannya, mampu mengakses sumber daya di luar lingkungannya, serta mengelola sumber daya tersebut untuk mengatasi masalah kemiskinan. Misi PNPM Mandiri Perdesaan adalah: (1) peningkatan kapasitas masyarakat dan kelembagaannya; (2) pelembagaan sistem pembangunan partisipatif; (3) pengefektifan fungsi dan peran pemerintahan lokal; (4) peningkatan kualitas dan kuantitas prasarana sarana sosial dasar dan ekonomi masyarakat; (5) pengembangan jaringan kemitraan dalam pembangunan.

Dalam rangka mencapai visi dan misi PNPM Mandiri Perdesaan, strategi yang dikembangkan PNPM Mandiri Perdesaan yaitu menjadikan masyarakat miskin 
sebagai kelompok sasaran, menguatkan sistem pembangunan partisipatif, serta mengembangkan kelembagaan kerja sama antar desa. Berdasarkan visi, misi, dan strategi yang dikembangkan, maka PNPM Mandiri Perdesaan lebih menekankan pentingnya pemberdayaan sebagai pendekatan yang dipilih. Melalui PNPM Mandiri Perdesaan diharapkan masyarakat dapat menuntaskan tahapan pemberdayaan yaitu tercapainya kemandirian dan keberlanjutan, setelah tahapan pembelajaran dilakukan melalui Program Pengembangan Kecamatan (PPK).

\section{Tujuan PNPM MP}

Tujuan Umum PNPM Mandiri Perdesaan adalah meningkatnya kesejahteraan dan kesempatan kerja masyarakat miskin di perdesaan dengan mendorong kemandirian dalam pengambilan keputusan dan pengelolaan pembangunan.

Adapun tujuan khusus PNPM Mandiri Perdesaan meliputi: a). Meningkatkan partisipasi seluruh masyarakat, khususnya masyarakat miskin dan atau kelompok perempuan, dalam pengambilan keputusan perencanaan, pelaksanaan, pemantauan dan pelestarian pembangunan; b). Melembagakan pengelolaan pembangunan partisipatif dengan mendayagunakan sumber daya lokal; c). Mengembangkan kapasitas pemerintahan desa dalam memfasilitasi pengelolaan pembangunan partisipatif; d). Menyediakan prasarana sarana sosial dasar dan ekonomi yang diprioritaskan oleh masyarakat; e). Melembagakan pengelolaan dana bergulir; f). Mengembangkan kerja sama antar pemangku kepentingan dalam upaya penanggulangan kemiskinan perdesaan.

\section{Prinsip Dasar PNPM MP}

Sesuai dengan Pedoman Umum, PNPM Mandiri Perdesaan mempunyai prinsip atau nilai-nilai dasar yang selalu menjadi landasan atau acuan dalam setiap pengambilan keputusan maupun tindakan yang akan diambil dalam pelaksanaan rangkaian kegiatan PNPM Mandiri Perdesaan. Nilai-nilai dasar tersebut diyakini mampu mendorong terwujudnya tujuan PNPM Mandiri Perdesaan. Prinsip-prinsip itu meliputi: a). Bertumpu pada pembangunan manusia, artinya masyarakat dapat memilih kegiatan yang berdampak langsung terhadap upaya pembangunan manusia dari pada pembangunan fisik semata; b). Otonomi yaitu masyarakat memiliki hak dan kewenangan mengatur diri secara mandiri dan bertanggung jawab, tanpa intervensi negatif dari luar; c). Desentralisasi yaitu memberikan ruang yang lebih luas kepada masyarakat untuk mengelola kegiatan pembangunan sektoral dan kewilayahan yang bersumber dari pemerintah dan pemerintah daerah sesuai dengan kapasitas 
masyarakat; d). Berorientasi pada masyarakat miskin artinya segala keputusan yang diambil berpihak kepada masyarakat miskin; e). Partisipasi artinya masyarakat berperan secara aktif dalam proses atau alur tahapan program dan pengawasannya, mulai dari tahap sosialisasi, perencanaan, pelaksanaan, dan pelestarian kegiatan dengan memberikan sumbangan tenaga, pikiran, atau dalam bentuk materil; f). Kesetaraan dan keadilan gender yaitu masyarakat baik laki-laki dan perempuan mempunyai kesetaraan dalam perannya di setiap tahapan program dan dalam menikmati manfaat kegiatan pembangunan,kesetaraan juga dalam pengertian kesejajaran kedudukan pada saat situasi konflik; g). Demokratis yaitu masyarakat mengambil keputusan pembangunan secara musyarawah dan mufakat; $h$ ). Transparansi dan Akuntabel artinya masyarakat memiliki akses terhadap segala informasi dan proses pengambilan keputusan sehingga pengelolaan kegiatan dapat dilaksanakan secara terbuka dan dapat dipertanggung jawabkan baik secara moral, teknis, legal, maupun administratif; i). Prioritas artinya masyarakat memilih kegiatan yang diutamakan dengan mempertimbangkan kemendesakan dan kemanfaatan untuk pengentasan kemiskinan; j). Keberlanjutan artinya dalam setiap pengambilan keputusan atau tindakan pembangunan, mulai dari tahap perencanaan, pelaksanaan, pengendalian dan pemeliharaan kegiatan harus telah mempertimbangkan sistem pelestariannya.

\section{Sasaran Dan Jenis Kegiatan PNPM MP}

Anonimous (2007) menjelaskan bahwa lokasi sasaran PNPM Mandiri Perdesaan meliputi seluruh Kecamatan perdesaan di Indonesia yang dalam pelaksanaannya dilakukan secara bertahap dan tidak termasuk kecamatan- kecamatan kategori kecamatan bermasalah dalam PPK/PNPM Mandiri Perdesaan. Sedangkan kelompok sasaran dari program ini yaitu a). Masyarakat miskin di perdesaan, b). Kelembagaan masyarakat di perdesaan, c). Kelembagaan pemerintahan lokal.

Pendanaan PNPM Mandiri Perdesaan merupakan program Pemerintah Pusat bersama Pemerintah Daerah, artinya program ini direncanakan, dilaksanakan dan didanai bersama-sama berdasarkan persetujuan dan kemampuan yang dimiliki oleh Pemerintah Pusat dan Daerah.

Adapun salah satu jenis kegiatan yang dibiayai melalui BLM PNPM Mandiri Perdesaan adalah Penambahan permodalan simpan pinjam untuk Kelompok Perempuan (SPP) 


\section{Pelaku Dan Perencanaan Kegiatan PNPM MP}

Masyarakat adalah pelaku utama PNPM Mandiri Perdesaan pada tahap perencanaan, pelaksanaan dan pelestarian. Sedangkan pelaku-pelaku lainnya di Desa, Kecamatan, Kabupaten dan seterusnya berfungsi sebagai pelaksana, fasilitator, pembimbing dan pembina agar tujuan, prinsip, kebijakan, prosedur dan mekanisme PNPM Mandiri Perdesaan tercapai dan dilaksanakan secara benar dan konsisten.

Sedangkan Perencanaan kegiatan PPK di Desa terdiri dari banyak tahapan antara lain terdiri dari : a). Musyawarah Antar Desa Sosialisasi; b). Musyawarah Desa Sosialisasi; c). Pelatihan Pelaku Tingkat Desa; d). Musyawarah Desa Khusus Perempuan; e). Musyawarah Desa Perencanaan; f). Penulisan Usulan Desa; g). Verifikasi Usulan Desa; h). Musyawarah Antar Desa Prioritas Usulan; i). Musyawarah Antar Desa Penetapan Usulan; j). Musyawarah Antar Desa Informasi Hasil MAD; k). Pengesahan Alokasi Bantuan oleh Camat; 1). Pengesahan Dokumen SPPB; m). Pelaksanaan Kegiatan.

\section{Program Simpan Pinjam Perempuan (SPP)}

Anonimous (2007) menerangkan bahwa Program PPK Fase I (1998-2002), terdapat juga program yang berupa pendanaan mikro usaha ekonomi produktif bagi pengembangan usaha kecil di pedesaan. Program pendanaan mikro pada umumnya dapat diakses oleh laki-laki dan perempuan. Kemudian pada program PPK Fase II (2002-2005), program melengkapi kegiatan pendanaan mikro dengan skema simpan pinjam perempuan. Simpan Pinjam Perempuan ini dikhususkan untuk perempuan untuk mengakomodir skema. Selain itu melalui program ini diharapkan kaum perempuan dapat menjadi katalisator peningkatan perekonomian rumah tangga miskin perdesaan di lokasi program.

Selanjutnya pada PPK fase III (2005), hanya dialokasikan dana untuk program SPP dengan alokasi dana maksimum $20 \%$ dari bantuan langsung masyarakat. Hal ini terjadi karena keberhasilan didalam penyaluran dan terjadinya peningkatan didalam pemanfaatan SPP dikalangan perempuan di perdesaan.

\section{Hipótesis Penelitian.}

Landasan teori, studi sebelumnya dan kerangka pemikiran yang di kemukakan bahwa peningkatan pendapatan masyarakat sebelum dan sesudah dipengaruhi secara positif dari program SPP-PNPM-MP di Desa Olak Rambahan dan Desa Selat. Atas dasar uraian diatas, maka hopotesis dalam penelitian ini seperti, Diduga bahwa program SPP-PNPM-MP di Desa Olak Rambahan dan Desa Selat Kecamatan 
Pemayung Kabupaten Batanghari, terdapat perbedaan peningkatan pendapatan masyarakat sebelum dan sesudah menerima program SPP-PNPM-MP tersebut.

\section{Metode Penelitian.}

Untuk menganalisis tingkat keberhasilan Pemberdayaan Masyarakat melalui Program PNPM-MP di Kecamatan Pemayung Kabupaten Batang Hari menggunakan metode survei. Menurut pendapat Singarimbun (1989) bahwa yang dimaksud dengan penelitian survei adalah penelitian yang menggunakan sampel sebagai pengumpul data pokok.

\section{Jenis Data dan Sumber Data}

Untuk menetukan jenis data yang dipakai dalam penelitian ini berupa Data Primer dan Data Skunder. Data Primer terdiri dari data pendapatan peserta SPP sebelum dan setelah adanya PNPM-MP, pendapatan peserta SPP di Desa Selat dan Desa Olak Rambahan atau yang sudah maju dan yang belum maju perkembangan SPP serta pendapatan peserta non SPP khususnya di lingkungan Kecamatan Pemayung Kabupaten Batang Hari.

Data Skunder terdiri dari data penduduk atas dasar usia, pendidikan pekerjaan, jumlah anggota keluarga, jumlah RTM, dan data jumlah BLM per Kecamatan lokasi penerima Bantuan Langsung Masyarakat, di lanjutkan dengan pengumpulan data, hasil penelitian lapangan, dengan melakukan 2(dua) tehnik observasi dan interview, dan penelitian kepustakaan (Librry Research), juga di lakukan metode penarikan sampel, analisis data ini dilakukan untuk kesempurnaan dalam penulisan.

\section{Hasil Pembahasan.}

Perbedaan pendapatan masyarakat sebelum penerima dan sesudah adanya SPPPNPM-MP Desa Olak Rambahan.

Hasil perhitungan dalam penelitian ini dengan menggunakan sofware komputerisasi yaitu dengan menggunakan program SPSS 17.0, dimana dari hasil tersebut deperoleh angka perhitungan berdasarkan permasalah pertama dalam penelitian ini seperti bagaimana perbedaan pendapatan masyarakat sebelum dan sesudah menerima program SPPPNPMMP di Desa Olak Rambahan. Kemudian untuk mempermudah menjelaskan hasil penelitian ini dapat dilihat pada tabel 4.2.1. seperti dibawah ini. 
Tabel. 4.2.1. Perbedaan pendapatan masyarakat sebelum penerima dan sesudah adanya SPP-PNPM-MP Desa Olak Rambahan.

\begin{tabular}{|c|c|c|c|c|c|}
\hline \multicolumn{6}{|c|}{$\begin{array}{c}\text { Paired Samples } \\
\text { Statistics }\end{array}$} \\
\hline & & Mean & $\mathrm{N}$ & Std. Deviation & Std. Error Mean \\
\hline \multirow[t]{2}{*}{ Pair 1} & SEBELUM SPPPNPMMP & $1.9463 \mathrm{E} 6$ & 40 & $1.87403 \mathrm{E} 6$ & $2.96309 \mathrm{E} 5$ \\
\hline & SESUDAH SPPPNPMMP & $3.3700 \mathrm{E} 6$ & 40 & $3.17040 \mathrm{E} 6$ & $5.01284 \mathrm{E} 5$ \\
\hline
\end{tabular}

Paired Samples Correlations
\begin{tabular}{|l|l|r|r|r|}
\hline & & N & \multicolumn{1}{|c|}{ Correlation } & \multicolumn{1}{c|}{ Sig. } \\
\hline Pair 1 & $\begin{array}{l}\text { SEBELUM SPPPNPMMP \& } \\
\text { SESUDAH SPPPNPMMP }\end{array}$ & 40 & .654 & .000 \\
\hline
\end{tabular}

Paired Samples Test

\begin{tabular}{|c|c|c|c|c|c|c|c|c|c|}
\hline & & \multicolumn{5}{|c|}{ Paired Differences } & \multirow{3}{*}{$\mathbf{t}$} & \multirow{3}{*}{ df } & \multirow{3}{*}{$\begin{array}{l}\text { Sig. (2- } \\
\text { tailed) }\end{array}$} \\
\hline & & \multirow[b]{2}{*}{ Mean } & \multirow{2}{*}{$\begin{array}{c}\text { Std. } \\
\text { Deviation }\end{array}$} & \multirow{2}{*}{$\begin{array}{l}\text { Std. Error } \\
\text { Mean }\end{array}$} & \multicolumn{2}{|c|}{$\begin{array}{l}95 \% \text { Confidence Interval of } \\
\text { the Difference }\end{array}$} & & & \\
\hline & & & & & Lower & Upper & & & \\
\hline $\begin{array}{l}\text { Pair } \\
1\end{array}$ & $\begin{array}{l}\text { SEBELUM SPPPNPMMP - } \\
\text { SESUDAH SPPPNPMMP }\end{array}$ & $-1.42375 \mathrm{E} 6$ & 2.40707E6 & $3.80591 \mathrm{E} 5$ & $-2.19357 \mathrm{E} 6$ & $-6.53933 \mathrm{E} 5$ & -3.741 & 39 & .001 \\
\hline
\end{tabular}

Bersadarkan hasil perhitungan pada Tabel paried samples statistics, diatas terlihat bahwa rata-rata pendapatan masyarakat desa Olak Rambahan sebelum mendapatkan program SPP-PNPM-MP adalah sebesar Rp.1.946.366 sedangkan pendapatan masyarakat sesudah SPP-PNPM-MP adalah sebesar Rp.3.370.066. Sementara itu perbedaan pendapatan setelah menerima program tersebut membuktikan bahwa program SPP PNPM MP layak untuk diteruskan. Peningkatan pendapatan masyarakat tersebut akan memberikan efek positif terhadap daya beli masyarakat sehingga akan meningkatkan kesejahteraan masyarakat. Kemudian perbedaan pendapatan masyarakat yang menerima program SPP PNPM MP dari 40 sampel tersebut mempengaruhi pendapatan masyarakat meningkat sebesar Rp.1423.700 atau 42.24 persen.

Kemudian pada tabel paried samples correlations yang menguji hubungan antara perbedaan pendapatan masyarakat sebelum dan sesudah menerima program SPPPNPM-MP adalah sebesar 0,654 atau sebesar 65.40 persen dengan nilai probabilitas $0,000<1$ adalah kuat dan signifikan. Dari hasil perhitungan tersebut menjelaskan bahwa hubungan perbedaan pendapatan masyarakat sangat signifikan, itu artinya program SPP-PNPM-MP memberikan dampak yang baik dalam kehidupan masyarakat.

Pada tabel paried samples test hipotesis dapat dijelaskan sebagai berikut; Ho = Sebelum SPP-PNPM-MP dan Sesudah SPP-PNPM-MP adalah sama Ha = Sebelum SPP-PNPM-MP dan Sesudah SPP-PNPM-MP adalah berbeda Dalam pengambilan keputusan berdasarkan hasil penelitian ini, salah satu caranya dengan 
membandingkan nilai probabilitas 0,005 dengan t hitung, artinya jika probabilitasnya $>$ 0,05 maka Ho diterima dan jika probabilitasnya < 0,005 maka Ho ditolak, kemudian jika t hitung $=-3,741$ sedangkan probabilitasnya sebesar $0,001(<0,005)$, maka Ho ditolak artinya pendapatan masyarakat Desa Olak Rambahan tidak sama sebelum dan sesudah SPP- PNPM-MP.

Perbedaan pendapatan masyarakat Sebelum dan Sesudah penerima SPPPNPM-MP Desa Selat.

Selanjutnya untuk menjawab permasalah bagaimana perbedaan pendapatan masyarakat sebelum dan sesudah menerima program SPPPNPMMP di Desa Selat dalam penelitian ini juga dibantu menggunakan sofware komputerisasi yaitu menggunakan program SPSS 17.0. Kemudian untuk mempermudah menjelaskan hasil penelitian ini dapat dilihat pada tabel 4.2.1. seperti dibawah ini.

Tabel. Perbedaan pendapatan masyarakat sebelum penerima dan sesudah adanya SPP-PNPM-MP Desa Selat.

\begin{tabular}{|c|c|c|c|c|c|}
\hline \multicolumn{6}{|c|}{ Paired Samples Statistics } \\
\hline & & Mean & $\mathrm{N}$ & Std. Deviation & Std. Error Mean \\
\hline \multirow{2}{*}{$\begin{array}{l}\text { Pair } \\
1\end{array}$} & SEBELUM SPPPNPMMP & $1.0434 \mathrm{E} 6$ & 100 & $8.87200 \mathrm{E} 5$ & 88719.96234 \\
\hline & SESUDAH SPPPNPMMP & $1.7001 \mathrm{E} 6$ & 100 & $9.94205 \mathrm{E} 5$ & 99420.49206 \\
\hline
\end{tabular}

Paired Samples Correlations
\begin{tabular}{|l|l|r|r|r|}
\hline & & $\mathrm{N}$ & Correlation & Sig. \\
\hline $\begin{array}{l}\text { Pair } \\
1\end{array}$ & $\begin{array}{l}\text { SEBELUM SPPPNPMMP \& } \\
\text { SESUDAH SPPPNPMMP }\end{array}$ & 100 & .721 & .000 \\
\hline
\end{tabular}

\begin{tabular}{|c|c|c|c|c|c|c|c|c|c|}
\hline \multicolumn{10}{|c|}{ Paired Samples Test } \\
\hline & & \multicolumn{5}{|c|}{ Paired Differences } & \multirow{3}{*}{$\mathrm{t}$} & \multirow{3}{*}{ df } & \multirow{3}{*}{$\begin{array}{l}\text { Sig. (2- } \\
\text { tailed) }\end{array}$} \\
\hline & & \multirow[b]{2}{*}{ Mean } & \multirow{2}{*}{$\begin{array}{c}\text { Std. } \\
\text { Deviation }\end{array}$} & \multirow{2}{*}{$\begin{array}{l}\text { Std. Error } \\
\text { Mean }\end{array}$} & \multicolumn{2}{|c|}{$\begin{array}{l}95 \% \text { Confidence Interval of } \\
\text { the Difference }\end{array}$} & & & \\
\hline & & & & & Lower & Upper & & & \\
\hline $\begin{array}{l}\text { Pair } \\
1\end{array}$ & $\begin{array}{l}\text { SEBELUM SPPPNPMMP - } \\
\text { SESUDAH SPPPNPMMP }\end{array}$ & $-6.56700 \mathrm{E} 5$ & $7.10101 \mathrm{E} 5$ & 71010.14368 & $-7.97600 \mathrm{E} 5$ & $-5.15800 \mathrm{E} 5$ & -9.248 & 99 & .000 \\
\hline
\end{tabular}

Pada tabel paried samples statistics, dapat dilihat bahwa rata-rata pendapatan masyarakat desa Selat sebelum mendapatkan program SPP-PNPM-MP adalah sebesar Rp.1.043.460, sedangkan pendapatan masyarakat sesudah menerima program SPP-PNPM-MP adalah sebesar Rp.1.700.160. Peningkatan pendapatan masyarakat di Desa Selat tersebut juga membuktikan bahwa program SPP PNPM MP layak untuk diteruskan. Berdasarkan hasil penelitian di dua Desa masing-masing 40 sampel dan 100 sampel membuktikan bahwa program SPP PNPMMP memberikan dampak yang sangat signifikan, dimana masing desa mengalami peningkatan pendapatan 
masyarakat. Peningkatan pendapatan masyarakat akan memberikan multiplier efek dalam pembangunan masyarakat dan daerah itu sendiri.

Kemudian perhitungan pada tabel paried samples correlations menguji hubungan antara pendapatan sebelum dan sesudah menerima program SPP- PNPM-MP adalah sebesar 0,721 atau 72.1 persen dengan nilai probabilitas sebesar $0,000<1$ artinya adalah kuat dan sangat signifikan.

Selanjutnya berdasarkan tabel paried samples test; hipotesis dapat dijelaskan sebagai berikut:

Ho $=$ Sebelum SPP-PNPM-MP dan Sesudah SPP-PNPM-MP adalah sama

$\mathrm{Ha}=$ Sebelum SPP-PNPM-MP dan Sesudah SPP-PNPM-MP adalah berbeda

Bahwa dalam pengambilan keputusan dalam penelitian ini, dengan membandingkan nilai probabilitas 0,005 dengan t hitung, artinya jika probabilitasnya $>$ 0,05 maka Ho diterima dan jika probabilitasnya $<0,005$ maka Ho ditolak, artinya jika $\mathrm{t}$ hitung $=-9,248$ sedangkan probabilitasnya sebesar

$0,000(<0,005)$, maka Ho ditolak artinya pendapatan masyarakat desa Selat tidak sama sebelum dan sesudah SPP-PNPM-MP.

Pinjaman SPP bermasalah, serta faktor-faktor yang menyebabkan keberhasilannya pinjaman penerima SPP PNPM Mandiri Pedesaan di Desa Olak Rambahan dan Selat Kecamatan Pemayung Kabupaten Batang Hari.

\section{Pinjaman SPP Bermasalah}

Adapun penyebab pinjaman SPP bermasalah Desa Olak Rambahan dan Selat secara umum adalah sebagai berikut:

i. Setoran anggota dipergunakan oleh ketua kelompok, kemudian setoran tersebut tidak di distribusikan kembali kepada sebagian anggota, atau tidak tranaspansinya sistem keuangan tersebut, sehingga menyebabkan terjadinya stagnan aliran dana.

ii. Meminjam dengan menggunakan nama orang lain, sehingga terjadi double pinjaman pada kegiatan yang sama, akibatnya pinjaman tersebut berdampak penipuan atau disebut dengan data fiktip, sehingga bila terjadi macet dalam pembayaran susah untuk di tagih.

iii. Ikatan pemersatu antar kelompok tidak kompak, sehingga mudah di propaganda oleh orang lain. Akibat lemahnya rasa kesatuan antar kelompok akan menyebabkan program susah tersebut untuk direalisasikan, sehingga 
munculnya kelompok-kelompok kecil yang saling menjelek-jelekkan antar teman dan kemudian mudah diadu domba baik dari interen maupun dari eksteren.

iv. Banyaknya anggota yang tersangkut pinjaman selain pinjaman SPP-PNPM- MP tersebut. Akibat banyaknya anggota yang tersangkut pinjaman akan menyebabkan kurangnya kemampuan untuk membayar, sehingga berdampak kepada hutang dan kemacetan dalam kelancaran program.

v. Memiliki kemampuan untuk membayar tetapi tidak memiliki iktikad baik untuk membayar hutang tersebut. Akibat dari lemahnya mental para anggota pinjaman dimana beranggapan bahwa dana pemerintah tidak mungkin dikembalikan, dengan alasan usaha tejadi bencana, seperti banjir atau kemarau sehingga disebut puso.

vi. Kurangnya kerja sama antar sebagian anggota, sehingga sulitnya untuk mengatakan satu pendapat dalam kemajuan program seperti dalam penetapan syarat administrasi pinjaman karena antar kelompok memiliki tujuan dan kepentingan masing-masing.

\section{Faktor-Faktor Penyebab Keberhasilan Pinjaman SPP PNPM Mandiri Desa Olak}

\section{Dan Desa Selat.}

Adapun faktor-faktor penyebab keberhasilan SPP juga ditentukan oleh program PNPM-MP yang memenuhi klasifikasi sebagai berikut:

a. Setiap setoran anggota dipergunakan untuk kepentingan kelompok dan kemudian setoran tersebut distribusikan kembali kepada anggota kelompok lain yang sudah terbentuk dan memenuhi syarat, sehingga terjadinya perputaran aliran dana dengan cepat secara tranaspansi dalam sistem keuangan.

b. Dalam memberikan pinjaman harus menggunakan nama yang bersangkutan sehingga tidak terjadi double pinjaman pada kegiatan yang sama, kemudian dalam memberikan pinjaman tersebut tidak terjadi penipuan atau disebut dengan data fiktip, serta bila terjadi macet dalam pembayaran mudah untuk di tagih.

c. Ikatan pemersatu antar kelompok sangat kompak sehingga tidak mudah untuk di propaganda oleh kelompok lain. Akibat kuatnya rasa kesatuan antar kelompok akan menyebabkan program mudah untuk direalisasikan, sehingga munculnya kelompok-kelompok besar yang saling mendukung antar teman 
kelompok. Dengan adanya rasa kesatuan antar kelompok tidak mudah untuk diadu domba baik dari interen maupun dari eksteren.

d. Setiap anggota hanya diberikan pinjaman SPP-PNPM-MP apabila tidak memiliki pinjaman ditempat lain, supaya anggota yang diberi pinjaman mudah untuk membayar, dan program tersebut menjadi lancar.

\section{Kesimpulan Dan Saran}

Kesimpulan

Dari hasil analisis data dan hasil pembahasan yang telah dikemukakan diatas, maka peneliti dapat menarik beberapa kesimpulan sesuai dengan tujuan umum PNPM Mandiri Pedesaan maka indikator keberhasilan pelaksanaan PNPM Mandiri Pedesaan adalah sebagai berikut:

1. Bahawa berdasarkan hasil perhitungan dalam penelitian ini terdapat perbedaan tingkat pendapatan masyarakat penerima SPP Mandiri Pedesaan sebelum dan sesudah adanya PNPM Mandiri Pedesaan seperti desa Olak Rambahan sebelum mendapatkan program SPP-PNPM-MP adalah sebesar Rp.1.946.366, sedangkan pendapatan masyarakat sesudah SPP-PNPM-MP adalah sebesar Rp.3.370.066, atau terjadi peningkatan sebesar Rp.1.423.700 atau 42.24 persen. Kemudian di desa Selat sebelum mendapatkan program SPP-PNPM-MP adalah sebesar Rp.1.043.460 sedangkan pendapatan masyarakat sesudah SPP-PNPM- MP adalah sebesar Rp.1.700.160 terjadi peningkatan sebesar Rp.656.700 atau 38.62 persen.

2. Berdasarkan hasil penelitian ini ternyata terdapat pinjaman SPP bermasalah yang disebabkan oleh setoran anggota dipergunakan untuk ketua kelompok tetapi setoran tersebut tidak di distribusikan terhadap sebagian anggota, atau tidak transparansinya sistem keuangan tersebut, serta Meminjam dengan menggunakan nama orang lain sehingga terjadi double pinjaman pada kegiatan yang sama. Selanjutnya faktor-faktor yang menyebabkan keberhasilannya pinjaman penerima SPP PNPM Mandiri Pedesaan di Kecamatan Pemayung Kabupaten Batang Hari seperti adanya musyawarah kelompok semua pengurus, sistem pinjaman diperketat atau melalui perifikasi, musyawarah dikelompok memiliki tanggungjawab yang sama, melakukan pendekatan-pendekatan antar perangkat desa. 
Saran

Adapun saran yang dapat diajukan dalam hasil penelitian ini adalah sebagai berikut:

1. Pendapatan masyarakat penerima SPP Mandiri Pedesaan sebelum dan sesudah adanya PNPM Mandiri Pedesaan terus ditingkatkan, kemudian dalam proses seleksi penerima SPP harus lebih selektif sesuai dengan aturan yang telah ditetapkan, kemudian progran PNPM Mandiri pendesaan dapat dilanjutkan bagi pemerintah pada tahun berikutnya, sehingga dapat mengurangi angka kemiskinan selain itu peningkatan pendapatan tersebut dapat mensejahterakan mayarakat terutama masyarakat Desa Olak Rambahan dan masyarakat Desa Selat maupun masyarakat Batang Hari secara umum.

2. Koordinasi antar kelompok harus terjalin dengan baik sehingga program PNPM-MP tersebut berkembang dengan cepat, selanjutnya setiap kelompok harus transparan dan bertanggung jawab.

\section{DAFTAR PUSTAKA}

Anonimous, 2009. Pedoman Umum Program Nasional Pemberdayaan Masyarakat Mandiri (PNPPM Mandiri). Kementrian Koordinator Bidang Kesejahtraan Rakyat.

Aprilianti Vinni, 2010. Analisis Tingkat Keberhasilan Pemberdayaan Masyarakat Melalui Program PNPM-MP Di Kabupaten Tanjung Jabung Timu. MEP. PPS. UNJA.

Asian Development Bank (ADB) 2008, Hasil Review dan Evaluasi atas Programprogram yang Berpihak pada Rakyat Miskin di Indonesia: Eko, Sutoro. 2012. Pemberdayaan Masyarakat Desa. Badan Pendidikan dan Pelatihan Provinsi Kalimantan Timur.

Hadad, Ismid, 2013. Pengentasan Kemiskinan Dalam Pembangunan Berkelanjutan dan Perubahan Pola Produksi yang Ramah Lingkungan Hadi Sutrisno, 2009. Metodologi Penelitian. Penerbit Ganesha Bandung. Kartasasmita Ginandjar, 2003. Pemberdayaan Masyarakat, Konsep Pembangunan yang Berakar pada Masyarakat, Institut Teknologi Bandung.

Lopez Agusto, 2015. Women's Empowerment: Measuring the Global Gender Gap. World Economic Forum.

Mulyani Sri, 2004. Strategi Nasional Penanggulan Kemiskinan. Makalah Seminar Nasional.

Napier A, 2003. Empowerment Theory, New York: Columbia University Press.

Nugroho Iwan dan Dahuri Rpkhmin, 2004. Pembangunan Wilayah: Perspektif Ekonomi, Sosial, dan Lingkungan LP3ES Jakarta Sumodiningrat Gunawan. 1996. Konsep Pemberdayaan Masyarakat Pedesaan. Makalah Seminar Nasional. 
UNDP United Nation Development Program, 2003. Laporan Indeks Pembangunan Manusia (IPM) Pangestu Marie dan Haryo Aswicahyono, 1996. Industrialisasi.

Keunggulan Bersaing dan Era Perdagangan Bebas dalam Pangestu, M. Raimon Atje dan Julius Mulyadi (Penyunting). Tranformasi Industri Indonesia Dalam Era Perdagangan Bebas, Jakarta CSIS.

Solfida Eleonora, 2003. Kontribusi Ekspor Industri Manufaktur Padat Sumber Daya Pertanian. Media Indonesia, Vol. 9, No 2. Jakarta: LP3E-KADIN Indonesia.

Tarigan R, 2004. Ekonomi Regional Teori dan Aplikasi. Penerbit Bumi Aksara Jakarta 